\title{
PENINGKATAN KEMAMPUAN KOMUNIKASI MATEMATIS SISWA SMP MELALUI PEMBELAJARAN INKUIRI MODEL ALBERTA
}

\author{
Muhammad Rizal Usman \\ Universitas Muhammadiyah Makassar \\ rizal.usman@unismuh.ac.id
}

\begin{abstract}
This research is motivated by the results of previous research which shows that students' mathematical communication ability is still not as expected. The focus of this research is to determine the improvement of students' mathematical communication ability as a result of the investigation of the Alberta model learning. This research is an experimental research with the population of all students of one of the State Junior High School in Bandung. The sample of the research is the grade VII students of the school. Samples were 73 students, 36 students of exprimental class and 37 students of control class. Based on the results of data analysis, it can be concluded that: (1) The achievement of mathematical communication ability of students who gain learning inquiry model Alberta better than students who learn conventional, (2) Improve the ability of mathematical communication, the thinking of students who gain learning inquiry model Alberta better than students Gain conventional learning, and (3) there is a difference in improving the ability of mathematical communication thinking based on the category of early mathematical ability.
\end{abstract}

Keywords: Mathematical Communication Ability, Alberta Model Inquiry

\section{PENDAHULUAN}

Matematika merupakan sebuah cara untuk berpikir, sebuah alat komunikasi, sebuah alat untuk mempelajari bidang ilmu lain, dan sebuah usaha intelektual (Konming dalam Yunarti, 2009). Dengan kata lain, matematika bisa dikatakan sebagai alat untuk mencapai tujuan, untuk dapat melatih siswa memiliki kemampuan berpikir. Tujuan diberikannya mata pelajaran sekolah yang telah paparkan sebelumnya, diharapkan bahwa setelah pembelajaran dilaksanakan siswa memiliki kemampuan matematis. Tapi dalam kenyataannya, setelah pembelajaran dilaksanakan ternyata sebagian siswa tidak memiliki kemampuan matematis yang diharapkan.
Kemampuan komunikasi merupakan suatu hal yang sangat penting pada masa sekarang, karena dampak yang diperoleh membuat manusia menjadi lebih terbuka, fleksibel dan dalam beradaptasi manusia mudah menghadapi berbagai situasi dan masalah kehidupannya. Perkembangan teknologi dan informasi yang lebih maju menuntut masyarakat harus lebih cerdas, kreatif, komunikatif dan mampu menyaring informasi yang diperolehnya.

Hadi (2012) menyatakan salah satu alasan perlunya siswa belajar matematika adalah bahwa matematika merupakan alat komunikasi yang sangat kuat, teliti, dan tidak membingungkan. Schoen, et. al (dalam Nurningsih, 2013) mengemukakan bahwa komunikasi matematis 
Peningkatan Kemampuan Komunikasi Matematis Siswa Smp Melalui Pembelajaran Inkuiri Model Alberta

Muhammad Rizal Usman

tidak hanya sekedar menyatakan ide melalui tulisan tetapi lebih jauh lagi yaitu kemampuan siswa dalam hal berbicara, membaca, menjelaskan, menggambarkan, mendengar, menanyakan, dan bekerjasama. Melalui kemampuan komunikasi matematis siswa dapat mengekspresikan pemahaman secara lisan ataupun tertulis, namun hal tersebut belum sepenuhnya dapat terlaksana karena masih banyak siswa yang kemampuan matematisnya tergolong rendah. Hal ini diantaranya dijelaskan dalam penelitian Subagiyana (2009) yang menunjukkan bahwa rata-rata kemampuan matematis siswa berada dalam kualifikasi kurang.

Hasil penelitian Setiawan (dalam Herlina, 2012) tentang kemampuan komunikasi matematis SMP juga menunjukkan bahwa perbedaan rerata antara kelompok kontrol dan eksperimen mencapai $20 \%$. Rendahnya hasil-hasil tersebut menunjukkan bahwa siswa belum mampu menggunakan komunikasi matematis dalam memecahkan masalah ataupun dalam menjalankan proses pemecahan masalah yang telah dilakukan. Hasil studi pendahuluan yang peneliti lakukan di salah satu SMP Negeri Bandung, dengan memberikan tes kemampuan komunikasi matematis kepada siswa kelas VIII.

Selanjutnya soal ini diujicoba dan dilakukan wawancara terhadap 5 orang siswa kelas VIII. Berdasarkan hasil studi pendahuluan yang peneliti lakukan terhadap sekolah yang akan dijadikan objek penelitian, diperoleh bahwa kemampuan komunikasi siswa masih rendah. masih banyak siswa yang tidak mampu menyelesaikan masalah yang diberikan, karena kurang memahami makna soal. Rata-rata per kelasnya hanya sekitar $12 \%$ saja yang dapat menyelesaikan soal tersebut.

Untuk mewujudkan siswa menjadi aktif dan memiliki kemampuan komunikasi matematis yang baik, tentu dibutuhkan model pembelajaran yang dapat mengeksplorasi dan melibatkan siswa secara aktif dan kreatif. Salah satu model pembelajaran yang dimaksud adalah pembelajaran Inkuiri Model Alberta. Belajar dengan pembelajaran inkuiri dapat melibatkan siswa dan memberikan pengalaman-pengalaman yang nyata. Siswa diharapkan dapat mengambil inisiatif sendiri, melatih dirinya mengaitkan materi-materi dalam matematika, memecahkan masalah, membuat keputusan dan memperoleh berbagai keterampilan atau kemampuan.

Belajar dengan pembelajaran inkuiri dapat meningkatkan kemampuan-kemampuan dalam diri siswa, yang dipaparkan oleh Nur (dalam Gani, 2007) yaitu kemampuan mengajukan pertanyaan dan menjawab pertanyaan-pertanyaan secara baik, kemampuan guru dapat mengajukan suatu pertanyaan atau mendorong siswa untuk mengajukan suatu pertanyaan-pertanyaan mereka sendiri. Kemampuan siswa belajar bagaimana menjadi ilmuwan, kemampuan untuk menyediakan pengalaman-pengalamn konkrit dan pembelajaran aktif bagi siswa, kemampuan agar 
siswa pada tingkat perkembangan berbeda bekerja pada masalah serupa bahkan bekerjasama dalam menemukan pemecahan masalah, kemampuan untuk dapat mengintegrasikan atas banyak disiplin, kemampuan berkomunikasi dengan baik, dan kemampuan agar siswa bertanggung jawab atas pendidikan mereka sendiri.

Pembelajaran ini memberikan kesempatan kepada siswa untuk: (1) mengembangkan keterampilan-keterampilan yang akan mereka butuhkan sepanjang kehidupan mereka; (2) belajar menghadapi masalah-masalah yang mungkin tidak memiliki solusi yang jelas; (3) berhubung dengan perubahan dan tantangan untuk pemahaman; dan (4) membimbing penyelidikan mereka untuk menemukan solusi pada saat sekarang dan di masa depan. (Alberta, 2004) Keterampilan yang diperoleh dalam pembelajaran ini penting dalam menyiapkan siswa untuk memecahkan masalah dan belajar seumur hidup. Dengan pembelajaran inkuiri model Alberta, usaha untuk meningkat kemampuan komunikasi matematis siswa yang dilakukan secara sistematik dengan memusatkan perhatian kepada proses belajar, dengan tujuan bahwa akan memberi peluang kepada semua siswa untuk melakukan kegiatan-kegiatan kreatif dalam pembelajaran matematika.

\section{METODE PENELITIAN}

Desain penelitian yang digunakan adalah nonequivalent control group design (Sugiyono, 2012).

Kelas Eksperimen: $\quad \mathrm{O} \quad \mathrm{X} \quad \mathrm{O}$

Kelas Kontrol:

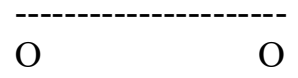

Penelitian ini terdiri dari variabel bebas, variabel terikat dan variabel kontrol. Variabel bebas adalah pembelajaran inkuiri model Alberta. Variabel terikat meliputi kemampuan komunikasi matematis siswa. Variabel kontrol adalah kategori awal matematis siswa sebelum diadakan penelitian.

Kategori kemampuan awal matematis (KAM) diperoleh dari data tes KAM siswa. Data tersebut diranking dan dikelompokkan menjadi kategori KAM tinggi, sedang, dan rendah berdasarkan rerata $(\bar{x})$ dan simpangan baku $(s)$ seperti yang dikemukakan Arikunto (2013) sebagai berikut:

1) Jika KAM $\geq \bar{x}+s$ maka siswa dikelompokkan ke kategori tinggi.

2) Jika $\bar{x}-s<\mathrm{KAM}<\bar{x}+s$ maka siswa dikelompokkan ke kategori sedang.

3) Jika $\mathrm{KAM} \leq \bar{x}-s$ maka siswa dikelompokkan ke dalam ke kategori rendah.

\section{HASIL DAN PEMBAHASAN}

\section{A. Hasil}

Berikut ini adalah sajian statistik deskriptif skor pretes, postes, dan $\mathrm{N}$-gain. 
Peningkatan Kemampuan Komunikasi Matematis Siswa Smp Melalui Pembelajaran Inkuiri Model Alberta

Muhammad Rizal Usman

Tabel 1. Statistik Deskriptif Kemampuan

Komunikasi Matematis Siswa

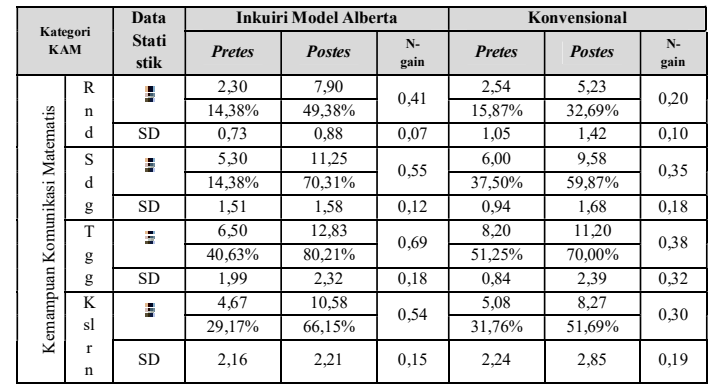

Hipotesis 1: Pencapaian kemampuan

komunikasi matematis siswa yang memperoleh pembelajaran inkuiri model Alberta lebih baik dibandingkan siswa yang memperoleh pembelajaran konvensional.

Tabel 2. Uji Perbedaan Rerata Skor Postes Kemampuan Komunikasi Matematis

\begin{tabular}{|c|c|c|c|c|}
\hline \multicolumn{3}{|c|}{$\begin{array}{c}\text { t-test for Equality of Means } \\
\text { (variances assumed) }\end{array}$} & Rerata & \multirow{2}{*}{ Ket. } \\
\hline$T$ & $D f$ & Sig (2-tailed) & 10,58 & \multirow{2}{*}{$\begin{array}{c}\mathrm{H}_{0} \\
\text { (vitok }\end{array}$} \\
\hline 3,899 & 71 & 0,000 & 8,27 & ditolak \\
\hline
\end{tabular}
matematis siswa kelas IMA dan konvensional.

Hasil uji independent simple t-test di atas didapat nilai $P$-Value atau Sig.(2-tailed) yaitu $0,000<0,05$. Hal ini menunjukkan bahwa $\mathrm{H} 0$ ditolak artinya terdapat perbedaan peningkatan kemampuan komunikasi matematis siswa kedua kelas. Kemudian dengan memperhatikan rerata kedua kelas, terbukti bahwa hipotesis yang menyatakan bahwa peningkatan kemampuan komunikasi matematis siswa yang memperoleh pembelajaran inkuiri model Alberta lebih baik daripada siswa yang memperoleh pembelajaran konvensional.
Hipotesis 2: Peningkatan kemampuan komunikasi matematis siswa yang memperoleh pembelajaran inkuiri model Alberta lebih baik dibandingkan siswa yang memperoleh pembelajaran konvensional ditinjau berdasarkan masing-masing kategori KAM *tinggi, sedang, dan rendah).

Tabel 3. Uji Perbedaan Rataan Skor N-gain Kemampuan Berpikir Kreatif Matematis Berdasakan KAM

\begin{tabular}{|c|c|c|c|c|c|}
\hline KAM & Kelas & N-Gain & Uji & Sign. & Но \\
\hline \multirow{2}{*}{ Rendah } & Eksp & 0,41 & \multirow{2}{*}{$\begin{array}{l}\text { Mann- } \\
\text { Whitney }\end{array}$} & \multirow{2}{*}{0,224} & \multirow{2}{*}{ Diterima } \\
\hline & Kont & 0,20 & & & \\
\hline \multirow{2}{*}{ Sedang } & Eksp & 0,55 & \multirow{2}{*}{$\begin{array}{l}\text { Mann- } \\
\text { Whitney }\end{array}$} & \multirow{2}{*}{0,003} & \multirow{2}{*}{ Ditolak } \\
\hline & Kont & 0,35 & & & \\
\hline \multirow{2}{*}{ Tinggi } & Eksp & 0,69 & \multirow{2}{*}{$\begin{array}{l}\text { Mann- } \\
\text { Whitney }\end{array}$} & \multirow{2}{*}{0,410} & \multirow{2}{*}{ Diterima } \\
\hline & Kont & 0,38 & & & \\
\hline \multirow{2}{*}{$\begin{array}{c}\text { Keseluru } \\
\text { han }\end{array}$} & Eksp & 0,52 & \multirow{2}{*}{ Uji t } & \multirow{2}{*}{0,000} & \multirow{2}{*}{ Ditolak } \\
\hline & Kont & 0,29 & & & \\
\hline
\end{tabular}

Untuk kategori KAM tinggi, dan rendah diperoleh nilai signifikansi lebih besar dari 0,05 berarti Ho diterima, dengan kata lain tidak terdapat perbedaan secara signifikan. Sedangkan untuk kategori KAM sedang dan keseluruhan diperoleh nilai sginifikansi lebih kecil dari 0,05 berarti Ho ditolak, dengan kata lain terdapat perbedaan secara signifikan. Dengan memperhatikan rerata n-gain, peningkatan kemampuan komunikasi matematis siswa kelas eksperimen lebih baik daripada kelas kontrol ditinjau dari sceara keseluruhan.

\section{B. Pembahasan}

Tujuan dari penelitian ini adalah untuk mengetahui pencapaian dan peningkatan kemampuan penalaran matematis siswa yang 
memperoleh pembelajaran inkuiri model Alberta lebih baik dibandingkan siswa yang pembelajaran pembelajaran konvensional.

Berdasarkan analisis data skor pretes kemampuan penalaranmatematis antara kelas eksperimen dan kelas kontrol tidak berbeda secara signifikan. Hal ini dapat dilihat dari perolehan rerata skor pretes kelas eksperimen yaitu 4,67 dari skor ideal 32, sedangkan perolehan skor pretes kelas kontrol yaitu 5,08. Meskipun kelihatan berbeda, namun setelah dilakukan uji kesamaan rerata skor pretes kelas eksperimen dan kelas kontrol menunjukkan tidak terdapat perbedaan signifikan antara skor pretes kemampuan komunikasi siswa kelas eksperimen dan kelas kontrol.

Setelah pembelajaran, skor postes siswa kelas eksperimen mencapai 10,58 dan memperoleh peningkatan 0,52 yang tergolong sedang, begitu juga siswa kelas kontrol yang mencapai 8,27 dan memperoleh peningkatan 0,29 yang tergolong rendah. Dari perolehan rerata postes kelas yang memperoleh pembelajaran inkuiri model Alberta lebih tinggi dari kelas yang memperoleh pembelajaran konvensional. Namun jika dilihat dari selisih perolehan rerata postes dan $\mathrm{N}$-gain, maka pencapaian dan peningkatan kemampuan penalaranmatematis siswa yang pembelajarannya memperoleh pembelajaran inkuiri model Alberta lebih baik dari siswa yang memperoleh pembelajaran konvensional.

Ditinjau dari klasifikasi gain ternomalisasi sebagaimana dikemukakan
Hake peningkatan kelas eksperimen berada pada kategori sedang, sedangkan untuk kelas kontrol berada pada kelas rendah. Ditinjau dari KAM pada kelas eksperimen, peningkatan (n-gain) berada pada kategori sedang. Ketiga kategori KAM pada kelas eksperiman berada pada kategori sedang dengan peningkatan secara keseluruhan yaitu 0,54. Pada kelas kontrol peningkatan (n-gain) berada pada kategori rendah secara keseluruhan dengan peningkatan 0,29. KAM sedang dan tinggi pada kelas kontrol berada pada kategori sedang, sedangkan untuk KAM rendah berada pada kategori rendah. Berikut hasil rangkuman disajikan pada Tabel 4.

Tabel 4. Rerata N-gain Kemampuan Komunikasi Matematis Siswa Berdasarkan Kategori

\begin{tabular}{|c|c|c|}
\hline$\frac{\text { KAM }}{\text { KAM }}$ & & \\
\hline & Eksperimen & Kontrol \\
\hline Rendah & 0,41 & 0.20 \\
\hline Sedang & 0,55 & 0,35 \\
\hline Tinggi & 0,69 & 0,38 \\
\hline Keseluruhan & 0,54 & 0,29 \\
\hline
\end{tabular}

Hasil penelitian juga menunjukkan bahwa faktor kriteria KAM siswa memberikan perbedaan yang signifikan terhadap peningkatan kemampuan komunikasi matematis siswa dan faktor pembelajaran baik pembelajaran inkuiri model Alberta maupun konvensional memberikan perbedaan yang signifikan terhadap kemampuan komunikasi matematis siswa.

Dapat disimpulkan bahwa terdapat perbedaan peningkatan kemampuan komunikasi matematis siswa yang memperoleh pembelajaran inkuiri model Alberta dengan siswa yang memperoleh 
Peningkatan Kemampuan Komunikasi Matematis Siswa Smp Melalui Pembelajaran Inkuiri Model Alberta

Muhammad Rizal Usman

pembelajaran konvensional ditinjau dari kelas inkuiri model Alberta dan kelas

kemampuan awal matematis siswa.

Secara keseluruhan berikut disajikan rangkuman hasil uji hipotesis terhadap kemampuan komunikasi matematis siswa. Hasil pengujian hipotesis tersebut dapat dilihat pada Tabel 5 berikut:

Tabel 5.1. Rangkuman Hasil Uji Hipotesis Kemampuan Komunikasi Matematis Siswa

\begin{tabular}{|c|c|c|}
\hline Hipotesis & $\mathrm{H}_{0}$ & $\mathrm{H}_{\mathrm{a}}$ \\
\hline $\begin{array}{l}\text { Pencapaian dan peningkatan } \\
\text { kemampuan komunikasi matematis } \\
\text { siswa yang memperoleh } \\
\text { pembelajaran inkuiri model Alberta } \\
\text { lebih baik dibandingan siswa yang } \\
\text { memperoleh pembelajaran } \\
\text { konvensional. }\end{array}$ & Ditolak & Diterima \\
\hline $\begin{array}{l}\text { Terdapat perbedaan peningkatan } \\
\text { kemampuan komunikasi matematis } \\
\text { siswa yang memperoleh } \\
\text { pembelajaran inkuiri model Alberta } \\
\text { dan siswa yang memperoleh } \\
\text { pembelajaran konvensional ditinjau } \\
\text { dari kemampuan awal matematis } \\
\text { siswa }\end{array}$ & Ditolak & Diterima \\
\hline
\end{tabular}

Berdasarkan hasil analisis data kemampuan komunikasi matematis, diperoleh temuan sebagai berikut: ditinjau berdasarkan kualitas peningkatan kemampuan komunikasi matematis siswa dapat dilihat berdasarkan klasifikasi Ngain. Nilai rerata pada kelas inkuiri model Alberta sebesar 0,52 berada pada klasifikasi sedang, sedangkan nilai rerata $\mathrm{N}$-gain pada kelas konvensional sebesar 0,29 berada pada klasifikasi rendah. terlihat dari rerata $\mathrm{N}$-gain kemampuan komunikasi matematis kelas inkuiri model Alberta lebih baik daripada kelas konvensional.

Temuan berikurnya adalah mengenai perbedaan rerata peningkatan kemampuan komunikasi matematis antar setiap kategor KAM konvensional. Berdasarkan uji perbedaan rerata $\mathrm{N}$-gain kemampuan komunikasi matematis siswa kategori rendah dan sedang yang memperoleh pembelajaran inkuiri model Alberta dengan siswa yang memperoleh pembelajaran konvensional tidak jauh berbeda. Namun, untuk siswa kategori KAM tinggi peningkatan kemampuan komunikasi matematis siswa yang memperoleh pembelajaran inkuiri model Alberta lebih baik daripada siswa yang memperoleh pembelajaran konvensional. Hal ini berarti untuk meningkatkan kemampuan komunikasi matematis, inkuiri model Alberta sesuai diterapkan pada siswa kategori KAM sedang.

\section{KESIMPULAN}

Pencapaian dan peningkatan kemampuan komunikasi matematis siswa yang belajar dengan pembelajaran inkuiri model Alberta lebih baik daripada dengan siswa yang memperoleh pembelajaran konvensional. Rerata skor postes pada kelas inkuiri model Alberta dan konvensional yaitu $10,58(66,15 \%)$ dan 8,27 $(51,69 \%)$, dari rerata skor postes kemampuan komunikasi matematis siswa kelas inkuiri model Alberta lebih tinggi daripada kelas konvensional. Untuk n-gain kelas inkuiri model Alberta lebih tinggi daripada kelas konvensional yaitu masingmasing 0,54 yang berada dalam kategori sedang dan 0,30 berada dalam kategori rendah. 


\begin{abstract}
Peningkatan kemampuan komunikasi matematis siswa yang belajar dengan pembelajaran inkuiri model Albertadan siswa yang memperoleh pembelajaran konvensional ditinjau ditinjau berdasarkan kategori KAM hanya berlaku pada kategori KAM sedang, siswa kelas inkuiri model Alberta memperoleh n-gain sebesar 0,55 dan kelas konvensional 0,35.
\end{abstract}

\section{REFERENSI}

Alberta L. (2002). Mathematics Preparation 10 Programs of Studies. Edmonton, AB: Alberta Learning. [Online]. Tersedia: http://www.learning.gov.ab.ac/k 12/curriculu m/bySubject/math/mathprep10.pdf. [12 Agustus 2013].

Alberta L. (2004) focus On Inquiry: A Teacher's Guided to Implementing Inquiry-based Learning. [Online].

Tersedia: http://www.education.alberta.ca/media/31336 1/focusoninquiry.pdf. [12 Agustus 2013]

Gani, R. A. (2007). Pengaruh Pembelajaran Metode Inkuiri Model Alberta Terhadap Kemampuan Pemahaman dan Pemecahan Masalah Matematik Siswa SMA. Disertasi SPS UPI: Tidak diterbitkan.

Hadi, S. (2012). Analisis Kemampuan Komunikasi Matematika melalui Model Think Talk Write (TTW) Peserta Didik SMPN 1 Manyar Gresik. Elektronik Jurnal Pendidikan Matematika Universitas Muhammadiyah Malang. [Online]. http://ejournal.umm.ac.id/index.php/penmath/ article/viewFile/611/633ummscientificjournal. pdf. [19 Desember 2013].

Herlina, S. (2012). Efektivitas Strategi REACT dalam Upaya Peningkatan Kemampuan Komunikasi dan Pemecahan Masalah
Matematis Siswa Sekolah Menengah Pertama. Tesis. SPS UPI: Tidak diterbitkan

Nurningsih, H. (2013). Meningkatkan Kemampuan Komunikasi dan Berpikir Kritis Matematis Siswa SMP Melalui Pembelajaran Berbasis Masalah dengan Strategi TeamsAsissted Individualization. Tesis. SPs UPI: Tidak diterbitkan.

Subagiyana. (2009). Peningkatan Kemampuan Pemahaman dan Komunikasi Matematik Siswa SMP Menggunakan Model Pembelajaran Koopertaif Tipe TeamsAssisted Individualization (TAI) dengan Pendekatan Kontekstual. Tesis. SPS UPI: Tidak diterbitkan.

Sugiyono. (2012). Metode Penelitian Kuantitatif, Kualitatif, dan $R \& D$. Bandung: Alfabeta.

Yunarti, T. (2009). Fungsi dan Pentingnya Pertanyaan dalam Pembelajaran. Seminar Nasional Matematika dan Pendidikan Matematika. Jurusan Pendidikan Matematika FMIPA UNY. 5 Desember 2009. [Online]. Tersedia: http://eprints.uny.ac.id/7023/1/output.pdf. [17 Oktober 2013]. 